Living Up to the Ads 
New Americanists A Series Edited by Donald E. Pease 


\section{Living Up}

to the Ads

Gender Fictions of the 1920s

Simone Weil Davis

Duke University Press Durham \& London 2000 
In slightly different versions, sections of chapter 4 of the present work appeared in French (translated by Maggy Chambon) as "La Mise en Scène des Femmes dans la Publicité," in Mimesis: Imiter, représenter, circuler, Hermes 22 (fall 1998): 167-77; and sections of chapter 5 of the present work appeared as " 'The Burden of Reflecting': Effort and Desire in Zelda Fitzgerald's Save Me the Waltz," in Modern Language Quarterly 56, no. 3 (September 1995): 327-61.

(C) 2000 Duke University Press

All rights reserved

Printed in the United States of America on acid-free paper $\infty$ Typeset in Adobe Garamond by Keystone Typesetting, Inc. Library of Congress Cataloging-in-Publication Data appear on the last printed page of this book. 